\title{
Local Economic Development of Coastal Community through Minapolitan Policy in Gresik Regency, Indonesia
}

\author{
Hevi Kurnia Hardini ${ }^{1}$ \\ $\left\{\right.$ hevi@umm.ac.id $\left.{ }^{1}\right\}$ \\ Universitas Muhammadiyah Malang $^{1}$
}

\begin{abstract}
This research investigates the implementation of Minapolitan Policy in Gresik Regency, East Java Province, Indonesia in developing local economic of coastal community. The roles of Gresik governments is analyzed within the context of decentralizations. The descriptive qualitative method is applied in order to capture detail facts, then it is described analytically. The data are collected by observation, in-depth interview, documentary and bibliography technique. There are three results of this paper. Firstly, the Gresik Regency has identified the potential commodities to be developed into minapolitan scheme in which concentrating more on cultivated fishery sectors and diversivication of processed fishery commodities. Secondly, the government optimizing its roles within the decentralisation schemes of empowering the fish-farmers and community in order to promote the marine resource production and local economic development. Lastly, The Gresik government is still dealing with the persistent problems such as (human resources, land convertion, infrastructures) than could only be solved collaborativery with many actors.
\end{abstract}

Keywords: Minapolitan Policy, Local Economic Development, Minapolitan Policy, Coastal Community and Blue Economy

\section{Introduction}

Indonesia has been officially concerned about the minapolitan development sector since the stipulation of the Ministry of Sea and Fisheries Affairs Regulation No 12 year 2010. This policy is aimed to accelerate the sea and fisheries development sectors in an integrated frameworks in which accommodating the complete steps of the pre-production; production; procession; marketing in an holistic and sustainable development. This scheme is also explored the comparative and competitive advantages of the existing coastal regions.

The minapolitan development is a consolidated program of National, Provincial and Regency/City Governments. According to the Indonesian decentralization concept, this is part of concurrent affair in which each level of government has their own coverage authority. This program is also in line with the Indonesian long terms development planning (RPJPN 20052025) in which advocating sustainable coastal-marine economic development. As it is also has been initiated by the former President of Indonesia (Susilo Bambang Yudhoyono) at the United Nation Conference on Sustainable Development (Rio+20) in 2012 as the Blue Economy Initiative in which increasing Indonesia's commitment towards its marine and fisheries sectors [1]. Afterwards, the minapolitan scheme is growing significantly as main goals under the administrative of the current President of Indonesia (Joko Widodo) in which 
Indonesia as The Global Maritime Fulcrum (GMF) doctrine had been stated at The East Asia Summit 2014. Thus it is formulated in five pillars "rebuild maritime culture; manage marine resources; develop maritime infrastructure and connectivity; advance maritime diplomacy and boost maritime defense forces". Simultaneously, the Presidential Regulation No. 16 Year 2017 regarding Indonesian Sea Policy was also stipulated [2].

Minapolitan development consist of minapolitan areas for fishery capture and fishery cultivation. Gresik Regency was determined by the Indonesian Government as one of minapolitan areas as it is imposed by the Ministry of Sea and Fisheries Affairs Regulation No 35 year 2013. According to this regulation, Gresik Regency is categorized as Minapolitan Area for Fishery Cultivation. Here are the selected areas namely: Sidayu, Ujung Pangkah, Bungah and Dukun Districs. In addition, Gresik regency has strategic existing condition in which possessing the availability of fishponds is up to $63 \%$ all out of the East Java Province Coverage. This consist of traditional fishponds $99,8 \%$; semi-intensive ponds $0,06 \%$ and intensive ponds $0,14 \%$. It means that, the main economic driven sectors is cultivated fishery resources.

In addition, there are also several regulations that support the improvement of sea and fisheries resources governance, especially in building the independence fishery cultivation sectors: The provision of superior quality fish seeds including strengthening of the local seed centers; Strengthening infrastructure and developing of cultivation areas (freshwater and brackish water); Independent feed and fish medicine; Certification of fish cultivator land; and Arrangement transport of live fish [3]. This is also been passed at the Ministry of Sea and Fisheries Affairs Regulation No 63 year 2017.

To be more specifically for analyzing minapolitan development within the context of decentralization, as it has been stipulated by the Act No 23 year 2014 that the authority scheme of Gresik Regency in the minapolitan development sector is described into two sectors. Firstly, in the fishery capture affairs, that are fisherman empowerment and fish auction centre management (Tempat Pelelangan Ikan-TPI). Secondly, in the fishery cultivation affairs, that are issuing fisheries business permit (Izin Usaha Perikanan-IUP), empowering small-businesses cultivation and managing fish cultivation in the coverage region. Here are the profile of Gresik Regency fisheries potencies:Methodology

Research on this sister city cooperation model used literature studies and interview methods to examine and understand how the sister city development model is good to be applied in Samarinda flood prevention. Qualitative research aims to explore and understand flood issues and provide an effective sister city cooperation model through community engagement in said problems. The interesting thing about this research is the creation of Samarinda city sister cooperation platform with the active involvement of the community in order to mitigate the flooding. Hopefully there are benefits gained for the citizen of Samarinda city through this collaboration.

The method that will be used in determining primary source data or an informant is purposive sampling through chosen sources. A chosen source is the person who has the capacity and capabilities according to the needs of the research. Data from the informant will add validity to the research that has been conducted. To facilitate the determination of the informant in the field, researcher targeted key informants from the local authorities of Samarinda city and community leaders in Temindung Village, Gunung Lingai Village, and Bengkuring area, the main areas affected by the biggest floods in Samarinda. 


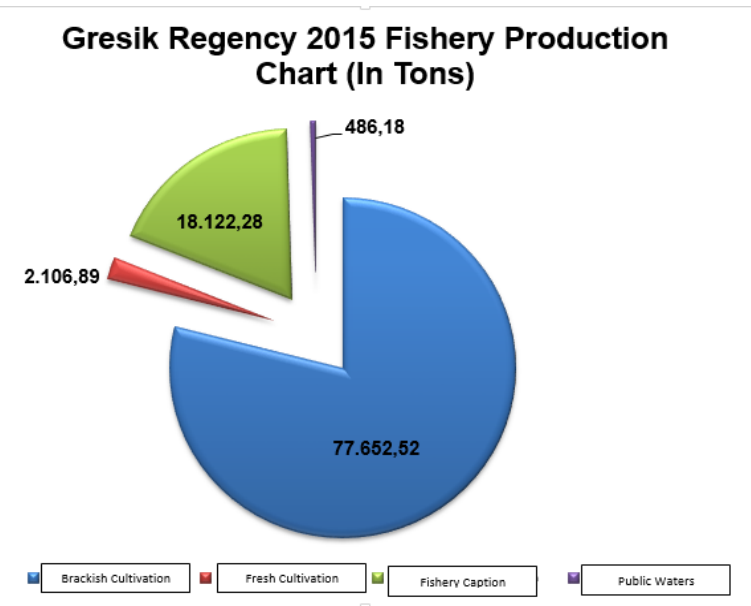

According to the figure 1 shows that the biggest potency is that brackish cultivation fisheries which is up to 77. 652,52 tons in 2015, thus in the minapolitan scheme development for Gresik Regency is mainly concerned on cultivation. However, the local government is facing several problems. The First, the limited availability of water since brackish cultivation is a man-made fishpond in which deal with the installation of piped water infrastructure. The Second, the high price of fish seeds especially with the high quality. The Third, the capital hardness for mostly traditional fish-farmers and it is also being worsened by the unintegrated capital instruments and institutions. The Fourth, the capability of fish-farmers in dealing with the sophisticated cultivation technology. The Fifth, the expensive of fish feed price. The Sixth, the roles of fish-farmers cultivation groups are not optimum yet in supporting the operational process. The Seventh, the number of fish-farmers are getting smaller, especially from the young generation. The eighth, the massive land conversion. The Last, the threat of pests and diseases that often drag the fish-farmers to the big lost. Therefore the study is purposed to investigate the finding that is also related to the implementation of minapolitan policy

\section{Method}

Study is applied the descriptive qualitative methods. This method is selected in order to get deep analytical towards the phenomena in which also aims to explore detail features of every phenomenon [4]. The participatory action research is also applied that involves several stages; Identifying reserach questions by being situated in the field to capture the phenomena; gathering information after the research question are formulated; analyzing and interpreting the information by cross-checking to the related informants; sharing the results as the media for verification before drawing conclusion [5].

The data are collected by observation (observant participatory) in the fields (Gresik Regency). In addition, several site-visits were conducted in cultivated fishponds; as well as observing the fish-farmers daily activities also the coastal community in order to get bigger picture. All the facts were sought and recorded through the observation journal research manually or electronically; in depth interview were conducted by applying purposive sampling for determining informants that reflects the governance actors (the representatives of the Gresik Regency Marine, Fisheries and Animal Husbandry; the coastal community (fishfarmers); NGO and the private sectors) then documentary and bibliography technique were proceed by selecting related sources that provide the secondary answer and explanation 
towards the research questions. This research is also applied descriptive method of analysis that passed through several stages such as: designing matrix and network displays, exploring, describing, ordering, explaining, predicting and drawing and verifying conclusions [6].

\section{Result and Discussion}

Potential Economy Identification as Minapolitan Area in Fishery Cultivation

Developing minapolitan means put all the related supporting sectors in one framework such as area based of sea and fisheries economy; strategic economy areas, production center and production units [7]. In addition, the model of minapolitan development in the scheme of cultivated fisheries is illustrated as the figure below:

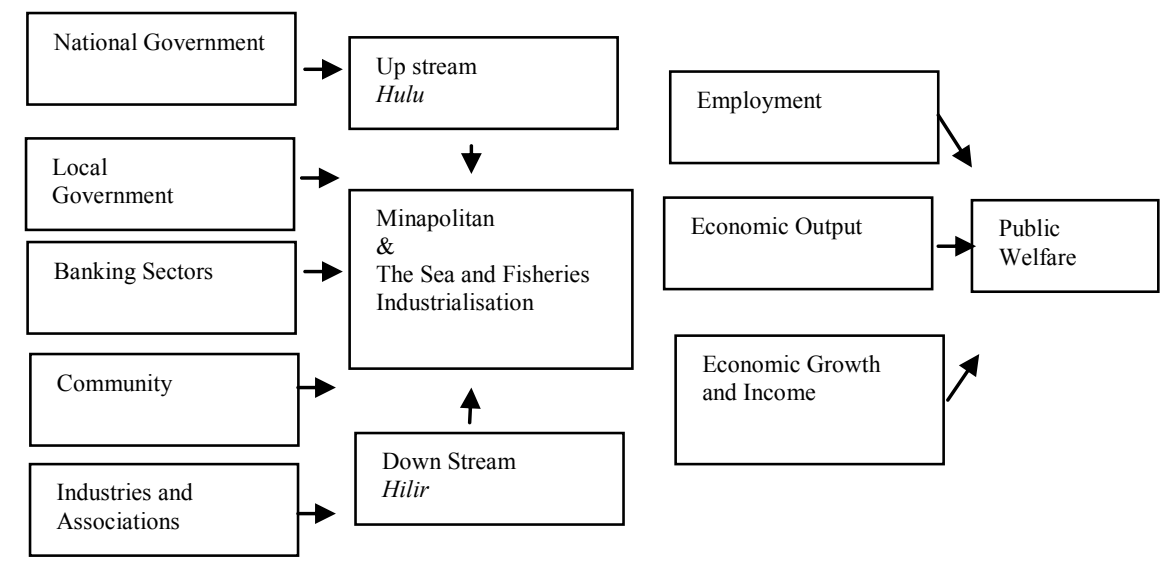

Figure 2. Minapolitan Development Synergy Model Sources: The Ministry of Sea and Fisheries, 2013

According to the figure 2, the integrated marine resources and productions are designed in order to achieve collectivity of advantages, efficiency and effectiveness in reaching the final goals. Since minapolitan development paradigm is tightly based on the identification of fisheries comparative and competitive advantages in the region, then the Gresik regency in 2017 has conducted economic of identification sectors, as its strategic roles that was made in optimizing minapolitan development as follows:

Table 1. Comparative Advantages Commodities in Gresik Regency

\begin{tabular}{|c|c|c|c|}
\hline $\begin{array}{l}\text { Fresh Cultivation } \\
\text { Commodity }\end{array}$ & Brackish Cultivation & ommodity & Processed Fishery Commodities \\
\hline 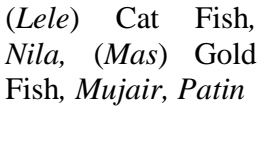 & $\begin{array}{lr}\text { Vannamei } & \text { Shrimp, } \\
\text { Windu } & \text { Shrimp, } \\
\text { Penokolan Bandeng }\end{array}$ & $\begin{array}{r}\text { Bandeng, } \\
\text { Kerapu, }\end{array}$ & $\begin{array}{l}\text { Fish and Shrimp Crackers, Abon, Dried Fish, } \\
\text { Fish Nugget, Fish Fillet, Smoked Fish, } \\
\text { Batasi, Fish Meatballs, Shrimp Paste, Ikan } \\
\text { Pindang, Petis and Otak-Otak, }\end{array}$ \\
\hline
\end{tabular}

Sources: Marine Department of Gresik Regrency, 2017 [8]

Those main potential commodities (Table 1) was scientificaly identified by the Gresik Regency for economic purposes, further this commodities would be developed by using minapolitan scheme and infrastructure. This is rational since The sea and fisheries industry deals with the many various uncertainty, hence this sectors have to be sustainably managed 
and supported by related stakeholders. Charles stated the uncertainty are categorized as natural factors (migration, mortality, predators-preys, multi species interaction etc.) and man-made factors (the market and price, operational cost, technology evolution, regulations, consumer behaviors etc.) [9]. In order to support the achivement of minapolitan goals, the local government also design all its programs for meeting the minapolitan outcome goals as below:

Table 2. Minapolitan Main Performance Indicators

\begin{tabular}{|c|c|c|}
\hline Fisheries Cultivation & Management \& Marketing & Income \& Employment \\
\hline $\begin{array}{l}\text { Increasing the productivity of } \\
\text { commodities (outcome) }\end{array}$ & $\begin{array}{l}\text { The quality and quantity } \\
\text { of fisheries value products }\end{array}$ & $\begin{array}{l}\text { Business opportunities and income } \\
\text { sectors for employments }\end{array}$ \\
\hline $\begin{array}{l}\text { Economic multiplayer effects } \\
\text { (outcome) }\end{array}$ & Diversification products & Public welfare \\
\hline $\begin{array}{l}\text { Increasing the quantity and } \\
\text { quality of production system }\end{array}$ & Increasing business units & $\begin{array}{l}\text { Income sectors for fisherman, } \\
\text { cultivators, and markets }\end{array}$ \\
\hline $\begin{array}{l}\text { The quality control for } \\
\text { cultivation process }\end{array}$ & $\begin{array}{l}\text { Marketing central system } \\
\text { Management business } \\
\text { development }\end{array}$ & \\
\hline
\end{tabular}

Sources: The Ministry of Sea and Fisheries, 2013

According to the table 2, indeed the minapolitan could accelerate the economic improvement of people and stakeholders in an efficient way. However, meeting the mina

B.Local Economic Development Programs for Coastal Community

As the purpose of minapolitan policy is that increasing the welfare people, especially in Gresik Regency which also be part of coastal community, hence the local government utilized its roles according to the decentralisation schemes for solving the problems. Here are several strategies that are designed and executed by the Gresik government. Firstly, improving the quality of the fish and seeds by using certified seed. Secondly, providing the availability of limited resources. Thirdly, encouraging Fish Cultivation Centre (Balai Budidaya Ikan-BBI) to produce superior seeds with sufficient quantities. Fourthly, establishing fish-farmer and group cooperation and opening easy capital access. Fifthly, optimizing available resources to increase production. Sixthly, improving fish health laboratory services in monitoring the cultivation environment to prevent the emergence of pests and diseases. Seventhly, improving water quality management and use fish which has a high tolerance for decreasing water quality Eighthly, improve coordination of all parties to make affordable economical feed. Lastly, Carry out facilitation and introduction of processing business through training and involving young generations

\section{Conclusion}

The greatest gratitue would be addressed to the University of Muhammadiyah Malang, in which has facilitated and made this research possible through the PDK Fundamental Research Scheme 2017-2018

\section{References}

[1] D. Dinarto, Indonesia's Blue Economy Initiative: Rethinking Maritime Security Challenges. Singapore: RsiS, 2017.

[2] E. Laksmana, "Indonesian Sea Policy: Accelerating Jokowi's Global Maritime Fulcrum?," in Asia Maritime Transparency Initiative, 2017.

[3] KKP, “The Strategic Planning 2015-2019." Jakarta, 2017.

[4] E. Thomas and J. . Magilvy, "Qualitative rigor or research validity in qualitative 
research,” J. Spec. Pediatr. Nurs., vol. 16, pp. 151-155, 2011.

[5] L. Berg, Qualitative research methods for the social sciences, 5th ed. The USA: Pearson, 2004.

[6] M. B. Miles, A. M. Huberman, and J. Saldana, Qualitative Data Analysis A Methods Sourcebook, 3rd ed. The USA: Arizona State University.

[7] Sunoto, “Arah Kebijakan Pengembangan Konsep Minapolitan,” Buletin Tata Ruang, BPN, Jakarta, 2016.

[8] Departemen kelautan gresik, "Data Update Maritime and Fisheries Potential." Gresik, 2017.

[9] A. Charles, Sustainable Fishery Systems. Fish and Aquaculture Resources, 5th ed. Canada: Saint Mary's University Halifax, 2001. 